\title{
The Control of Environment Management Through Administrative Court
}

\author{
Aju Putrijanti ${ }^{1, *}$ \\ ${ }^{1}$ Faculty of Law, Diponegoro University,Semarang - Indonesia
}

\begin{abstract}
Environment is important in human life. Conflict of interest comes between development of economy sector, citizenship needs and Governance, as it becomes completely difficult to analyze. The environment's lawsuit is increase from the beginning of the Court established. The duty of Administrative Court are to investigate, decide and settle administrative disputes. The Governance has to pay attention before issuing the Government's decree by put principle of good governance as priority. The issue in this paper is strengthening the role of Administrative Court to maintain the environment reuse by settle environment disputes based on the importance of environment. The administrative decisions in environment field may cause a loss or damage for the people. When the public officer did not put the appreciation to the reuse of environment and principle of good governance, it will become problems. The decision should be environmentally friendly. There should be certified judge to settle the dispute. The method of this research by examines the Judge's verdict in environment disputes, and its relation with regulations and the newest issues. The conclusion is increase the role of the Administrative Court to maintain the environment by law enforcement through settle environment disputes.
\end{abstract}

\section{Introduction}

Environment is very important for human life, we depends on the sustainability of it. It is important to control the environment management by the Government. The Government has a power based on Constitution to supervise it. As stated in Article 28 section (1) that everyone has rights to live with prosperity, residence, get a well and healthy environment, health services. The development in every sector should regulate quite well because there will be conflict of interests. This appears between private sector, government, citizenship as stakeholder of environment. The issue in this article is how to strengthening the role of Administrative Court to maintain the environment reuse by settle environment disputes based on the importance of environment.

\section{Method}

This research is use judge's verdict as secondary data, besides regulations. In this judge's verdict, we can know the legal consideration. Legal consideration is important, because it shows the judge's thinking of the case and maybe there is an important opinion for the development of law.

\section{Discussions}

\subsection{Administrative court}

The idea of Administrative Court came from F.J. Stahl in Rechtsstaat, as one of the elements of State, in Civil Law System, and to protect citizenship from abuse of power by government. On the beginning, the Administrative Court started in France, followed by Dutch, Germany and some European country.

Concept of Administrative Court in Indonesia are to protect the human rights, and independence of judiciary system. Administrative Court has to control government's act in public sector, by cancel the decree which against the law.

Administrative Court is one of the judiciary body under The Supreme Court based on Article No. 24 section (2) of Constitution. The competence is to investigate, decide and settle administrative disputes. The disputes are between the individual or private company as Defendant and the Government as Plaintiff, with administrative decree as an object to the Court. Due to the fast changing in every sector as implication of development, the environment's lawsuit increase. The lawsuit put in the Court with claim to cancel the government's decree as an object.

The main part in Judge's verdict is law consideration by Judge. Judge will give explanation based on law and knowledge. Judge has freedom to explain his consideration as one of the independence of judiciary, without intervention.

\footnotetext{
Corresponding author: aputriyanti@yahoo.com
} 


\subsection{Government}

In the welfare state, the government has a wide range to supervise the management of every sector to develop the nations. Government has to put principles of good governance along with the law. Principles of good governance as a norm, unwritten law, guidance is to govern the government. The British and Irish Ombudsman Association put ten guide principles, i.e.: independence, effectiveness, openness and transparency, accountability, integrity and clarity of purpose [1].

The different characteristic by UN Economic and Social Commission for Asia and the Pacific, i.e: participatory, consensus oriented, accountable, transparent, responsive, affective and efficient, equitable and inclusive and follows the rule of law. In Law No 30 Year 2014 of Governance Administration, Article 10 verse 1 , there are 6 ( six) principles of good governance i.e : legal certainty, expediency, impartiality, accuracy, not abuse the authority, openness, public interest, good service.

In a modern state, government has to cooperate with private sector in order to develop the country. Private sector has to ask permission from government, and government's decree issue for the certain purpose. It becomes an object to Administrative Court when it's infringe the law.

\subsection{Environment}

Environment is actually global in nature, it is multidisciplinary subject including physics, geology, geography, history, economic, physiology, biotechnology, remote sensing, geophysics, soil science and hydrology, etc. Environment is sum total of water, air and land interrelationship among themselves and also with the human being other living organism and property [2].

\subsection{The control of administrative court}

To build a plant, private sector must get a permission decree from relevant government's office. In 2009 there was administrative dispute with Decree of Chief of Integrated Licencing System in Pati No. 540/040/2008 dated 5 November 2008 re Mining Permission Exploration Region of Karst In Section C. on behalf Ir. Muhammad Helmi Yusron as an object. Defendant is Yayasan Wahana Lingkungan Hidup Indonesia (WALHI). The aim is to cancel the decree because it against the law and principle of good governance.

Administrative Court has its special principle, that Judge must be active (dominus litis, actieve rechter) so he can decide who has to prove, what has to prove, what should be proven by the party, what should be proven by the Judge, tools of evidence and the strengthen of the evidence. The Court granted the Plaintiff's claim and stated that first, formally procedural, the decree has followed the law. AMDAL's document based on Article 15 verse (1) Law No 23 Year 1997 should be completed, and did not respect to indigenous people. This was against the principle of good governance, i,e., principle of openness, principle of wisdom, principle of protecting the way of life.

Judges not only based on legal positivism, but also on socio cultural, because environmental has a multidisciplinary approach along with progressive law which has a dynamic evolutive character. As stated in Article 28 verse (1) Law No 4 Year 2004 of Judiciary Power, Judge has to dig, follow and respect value of law and sense of justice in civilization.

In the appeal of Administrative Court No 138/B/2009/PTTUN. Srby dated 30 November 2009, the Judges cancel the judge's verdict in the first level. The Supreme Court cancelled the judge's verdict of Pengadilan Tinggi Tata Usaha Negara (PTTUN) Surabaya. In this case, the Supreme Court granted the Plaintiff's claims and accepted their last legal effort.

Based on article by De Hoon and Verberk, that the new judge involved in the needs of litigants and its decides, together with ( and not for) the litigants, which dispute resolution is the best chances for viable and sustainable decision [3]. This is a new approach to settle dispute, when it is necessary to implement. The use of the new approach should be wisely and properly.

Judges use the independence by put the indigenous principle of Sedulur Sikep in a proper way, and to maintain the reuse of environment with their customary. The role of Judge is important, especially in the modern governance, as a part of judicial governance, it has to follow and change the way of thinking, modernization of the court, also management of the court.

Judicial independence requires that judge impartial and unbiased when they judging, in order to keep trust on the case, as stated by Gar Yein Ng. [4]. It is important to look in a broader view the meaning of judicial independence, and it must relevant with the case, local norms and values The respect of principle of protecting the way of life shows that there is a philosophy thinking for reuse of environment. Judges collaborate between the principle of protecting the way of life, reuse of environment, Constitutional rights in appropriate legal reasoning, this could be a new way to control the environment management. It is necessary to use sociolegal approach to settle dispute it is means that we can use positive law, unwritten law included valuable principles in society, habits, traditions or in another way, we have tried to combine the use of doctrinal and non doctrinal approach [5].

In the environment dispute as above, there should be consider wisely because it is also involve the indigenous people with their belief. On the other side the law has to be obey and enforced. This approach is needed to understand between the law and the case, and might be appropriate in the development country [6].

In another case of administrative dispute, between Plaintiff and Defendant, with object the Governor's Decree of Environment Permit of Mining and Developing Plant Factory of Cement of PT Semen Indonesia in Rembang District Central Java Province No. 660.1/17 Year 2012 dated 7 June 2012. In the first Administrative Court, the Judge's verdict was refuse the suit, because it was over the period scheduled. In the Article 55 of Law No 5 Year 1986 of Administrative 
Act, stated that the lawsuit should be submitted in 90 days after announced or informed to the applicant.

In the appeals court, has stated that they affirmed the first Administrative Court's verdict. Judges's have the same opinion and legal reason with the first Court. In the judicial review by The Supreme Court, it has withdrawn the second Court's verdict, and has its own legal reason.

One of the important legal reasoning of the Supreme Court was that they put principle of good governance as guidance to government to took prior of refuse the damage rather than the benefit. The principle of prudent and punctilious as the principle of good governance which should be used in this case.

Judges said that in processed of AMDAL's document, did not followed the regulations neither the principle of continuity, principle of prudent and punctilious. The supporting documents of AMDAL is very important, that is why it should be based on principle of good governance as well as regulations.

The different legal reasoning of the Judges, was important. It showed the independence of judiciary, and judge has to explicate their opinion based on law. To build a good governance, this is strongly needed in judiciary system.

There are some interested points in the two judge's verdict. First, both are administrative disputes of mining permission. This mining's project related with Sedulur Sikep an indigenous community, which had lived for century in the mining's area project, and they have their own way to reuse the environment.

Second is the different legal reasoning from judge when they consider and decide the dispute. One is using sociolegal approach to analyzed, and the other using normative approach, although in the last effort of the Supreme Court, it seems that judge using sociolegal approach but did not mention clearly.

Third this is another way to control the use of environment through Administrative Court. The judge's verdict which used sociolegal approach to settle administrative dispute in mining permission, is a good idea and possible to develop in forthcoming dispute.

The cancellation of government's decree is a control of environment. With consideration to respect the Sedulur Sikep way of life in reuse of environment, not only based on normative. Culture is important role and in a system of law as stated by Friedman, besides structure and substance of law.

Culture in each state and society has an important role to build the nations. In Indonesia, it is plural and heterogenous, and its has Adat Law for each region.

The decree of government is object to Administrative Court and it gives permission to applicant to use the environment. In the concept of welfare state, there are govenrment, society and private sector which collaborate to develop the state. This concept is vary in every state, depends on the ideology and aims of the state [7].

Government has an authority to control the environment, but on the other side there is an economic interest for development, and the decree is issued by the government. The permission to use the environment, actually as an instrument to protect it, but it had changed as caused of the environment contamination. Hikmahanto Juwana also said that government is able to become Defendant [8].

Administrative Court has to control the government's duty, because it is related with the well being for everyone, and to fulfill the constitution's rights to civil and political right. There are regulations which should be followed before issued decree.

The principle of good governance is important and should be as a legal basic in issued the decree. This is a universal principle, it means that this principle is use in every state to run the state. Since every state has its own philosophy, ideology and aims, so the principles will be adjust. Principle of good governance as an ethic and guidance for government to perform the State [9]. This is now become as a positive law as stated in Law No 30 Year 2014 of Administrative Governance, so it has more strengthen as legal basis.

Furthermore the control by Administrative Court as implementation to get access of justice in environmental disputes. This sociolegal approach can be use as a new method to get access of justice, since the disputes is multidisciplinary. As a comparative study from Brazil, in the article "Access to environmental justice in Brazil ", the legal environmental system is the possibility of inserting legal - environmental conflicts in the legalinstitutionalsphere, which influencing the elaboration of final decision, which must be guided in the principle of environmental justice [10]. This means that to settle disputes of environment and to get access to environment justice, there should be comprehensive approach, and fair justice in court.

\section{Conclusion}

Control of environment management can be done by Administrative Court by cancel the government's decree which against the principle of good governance and law. Before issue the decree, government has to consider the principle of good governance as legal basis correctly and wisely.

Principle of good governance has to be used as a legal basis to control the environment reuse. Related to the dispute by put respect on principle of protecting the way of life, principle of wisdom, principle of openess are part of principle of good governance which is vary in every State.

Sociolegal approach can be used as a method to control the reuse of environment, because its combine the law and social value of society. This approach might be developed by Judge with mature legal basis and appropriate dispute.

\section{References}

1. https://www.bioa.org.uk

2. www.unescap.org

3. De Hoon \& Verberk. http://www.utrechtlawreview.org Volume $\mathbf{1 0}$ Issue 4 (November 2014). 
4. Gar Yein Ng. http://www.utrechtlawreview.org Volume 7, Issue 1, (January 2011).

5. Sarah Blandy. Pp 166 - 175.(2014). http://eprints.whiterose.ac.uk/

6. Sulistyowati Irianto. "Memperkenalkan Studi Sosiolegal dan Implikasi Metodologisnya" dalam Metode Penelitian Hukum Konstelasi dan Refleksi.Jakarta : Yayasan Pustaka Obor Indonesia.pp. 173-175.(2011).

7. Mohammad Tavip. "The Dynamic Concept of Welfare State in Indonesian Constitution". Doctoral Program of Legal Studies, Faculty of Law, Brawijaya University, Malang, pp. 1-17., (2013). Download.portalgaruda.org.artikel/php
8. A'an Effendi. Hukum Penyelesaian Sengketa Lingkungan. (Jakarta : Sinar Grafika. Pp. $10-$ 11, 2016)

9. Hotma P. Sibuea. "Asas-asas Umum Pemerintahan yang Layak Sebagai Sarana Penguji Peraturan Kebijakan dalam Perspektif Negara Hukum Kesejahteraan" dalam Asas Negara Hukum, Peraturan Kebijakan dan Asasasas Umum Pemerintahan yang Baik. Jakarta: Erlangga. pp. 152. (2010)

10. Mariana Almeida Passoss de Freitas. International Journal of Court Administration.Special Issue Vol.8, No. 3. (July 2017). URL http://www.iacajournal,org 